\title{
PERITONEOVENOUS SHUNT - MODIFICATION WITH THE USE OF LONG SAPHENOUS VEIN
}

\author{
Petr Utíkala , Petr Dráča , Petr Bachledaa ${ }^{\mathrm{a}}$, Jiři Kleinº, Vladimír Král ${ }^{\mathrm{b}}$, Monika Hrabalová \\ a $2^{\text {nd }}$ Clinic of Surgery, Teaching Hospital Olomouc, Czech Republic \\ ${ }^{b} I^{\text {st }}$ Clinic of Surgery, Teaching Hospital Olomouc \\ e-mail:petr.utikal@fnol.cz
}

Received: April 5, 2004; Accepted: June 11, 2004

Key words: Ascites/Peritoneovenous shunt/Saphenoperitoneal shunt

The authors describe their own initial experience with saphenoperitoneal modification of the peritoneovenous shunt in intractable ascites solution. Their findings with this easy type of permanent ascites drainage using the "patient's own resources" are puzzling.

\section{INTRODUCTION}

Peritoneovenous shunt (PVS) plays a major role in the surgery of intractable ascites in patients with liver cirrhosis $^{1-7}$. A permanent peritoneal cavity drainage with return of ascitic fluid into the circulation based on positive pressure gradient between peritoneal cavity with ascites and central venous pressure is the principle. A number of drainage systems have been developed over the course of time. Currently systems, which permit active flow management (Denvers shunt) enabling us to retain long-term cumulative function, are optimal ${ }^{8,9}$. Their only disandvantage is high costs. Therefore attention has been paid to modification using "patient's own resources" as described by H. J. Vadeyar et $\mathrm{al}^{10}$. Here the long saphenous vein is used as a drainage system (Fig. 1). One-way ascites flow is ensured by a natural valve in the saphenous orifice ${ }^{10}$.

\section{METHODS}

When deciding a PVS formation, the present criteria for indications and contraindications have been foremost for us. Presumptions for sapheno - peritoneal modification of PVS are patent femoro-iliaco-caval portion of the deep venous system and suitable long saphenous vein with sufficient orificial valve.

The procedure is performed under general anaesthesia and all patients receive perioperative antibiotics and heparin (LMWH). The long saphenous vein is exposed through vertical incision, its branches are ligated and it is divided at $20 \mathrm{~cm}$. In simple mechanic manner (catheterization with saline solution flush) we check central patency of the saphena and sufficiency of its orificial valve (no backflow from the femoral vein). The inguinal canal is exposed through an oblique incision and we disclose the parietal peritoneum after division of the internal oblique muscle fibers laterally from the spermatic cord (funiculus) in the internal ring. This is the place for incision in the peritoneum. The proximal cut end of the long saphenous vein is turned upwards and pulled through the subcutis above the inguinal ligament. We form a slight curve in the venous orifice to prevent a sharp bend. We cut the peritoneum and perform a watertight anastomosis with obliquely cut saphenous end using a continuous prolene 6.0 suture (Fig. 2). The pressure of ascites on the suture can be reduced by Trendelenburg's position. The wounds are closed in layers without any drain. Subsequent care of the patient with a mobilised ascites and shunt is the same as in other types of PVS.

To perform better peritoneal drainage we have suggested a modification with a silastic catheter whose fenestrated peritoneal end $(25 \mathrm{~cm})$ is placed in the peritoneal cavity with saphenous end reaching vein just bellow the valve (Fig. 3).

\section{RESULTS}

Between 1999 and 2001 we performed in all 12 shunts of this type in 6 patients with tension intractable ascites in liver cirrhosis, Child-Pugh-Turcott classification from 7 to 12 .

3 shunts in 2 pts were performed using a peritoneal catheter.

There was no function in 2 shunts, only intraoperative ascites drainage was evident. 8 shunts failed in 36 hours after a transient reduction of tension ascites. 1 patient with a functional shunt (with a peritoneal catheter) died 3 weeks later due to a concomitant disease. Only in 1 patient (after primary shunt failure and contralateral secondary one formation) we can claim long-term ( 3 months) successful function. The patient has only residual ascites. We reoperated (from the groin access and venotomy) 


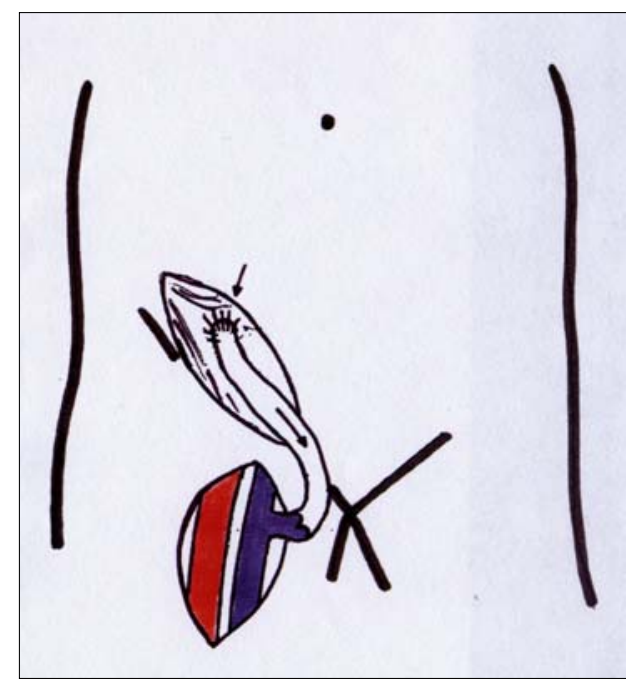

Fig. 1. Scheme of saphenoperitoneal shunt

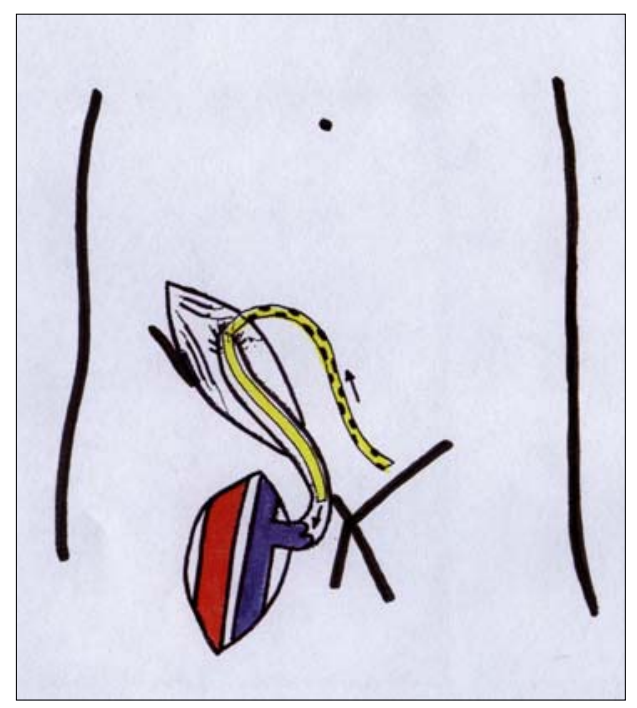

Fig. 3. Scheme of saphenoperitoneal shunt - modification with a silastic catheter

due to early shunt failure in 6 pts 15 times in all. We experienced inflow failure in 9 cases - omentum stuck the anastomosis very probably, no technical mistake in the anastomosis was found. We delivered bend in the venous orifice in 1 shunt. Outflow failure, saphenous vein thrombosis, we found in 5 cases. In the case of primary shunt failure (repeated) we performed a shunt of the same type contralaterally.

When we were not succesful with the contralateral shunt we performed a Denver shunt.

We had no relevant hemorrhage, infection or ascitic leakage complications. No patient died in relation to either primary surgery or surgery for shunts complications.

\section{CONCLUSION}

At first saphenoperitoneal shunt is an indisputably elegant and easy type of intractable ascites permanent drainage. Our results are puzzling. The advantage of autologous material using, possibility of formation of the same shunt contralaterally and low cost in our group do not balance the frequency of shunt occlusion with problematic solution.

Comparison of various departments experiences as well as evaluation of long-term results is missing. References to this type of shunt are still sporadic. Based on these facts we cannot recommend this modification of PVS.

\section{REFERENCES}

1. Le Veen HH, Christoudias G, Moon I P. (1974) Peritoneovenous shunting for ascites. Ann Surg 180, 580-591.

2. Zühlke HV, Häring R, Semsch B. (1984) Der peritoneo-venose Shunt zur Behandlung des therapieresistenten Ascites. Chirurg 55, 253-259.

3. Schumpelick V, Riesner KP.(1993) Peritoneo-venoser Shunt-Indikation, Grenzen, Ergebnise. Chirurg 64, 11-15.

4. Hillaire S, Labianca M, Borgonovo G.(1993) Peritoneovenous shunting of intractable ascites in patients with cirrhosis: Improving results and predictive factors of failure. Surgery 113, 373-379.

5. Elcheroth J, Vons C, Franco D. (1994) Role of surgical therapy in management of intractable ascites. World J Surg 18, 240-245.

6. Utíkal P, Král V, Bachleda P, Klein J. (1997) Peritoneovenózní spojka v chirurgické léčbě ascitu u nemocných s cirhózou jater. Rozhl Chir 76, 497-501.

7. Zervos EE, Rosemurgy AS. (2001) Management of medically refractory ascites. Am J Surg 181, 256-264.

8. Lund RH, Newkirk JB. (1979) Peritoneovenous shunting system for surgical management of ascites. Contemp Surg 14, 31-38.

9. Lund RH, Mortitz MW. (1982) Complications of Denver peritoneovenous shunting. Arch Surg 11, 924-928.

10. Valdeyar H J, Doran DJ, Charnley R, Ryder S D. (1999) Saphenoperitoneal shunts for patients with intractable ascites associated with chronic liver disease. Br J Surg 86, 882-885. 